\title{
Diamond Based Composites
}

and Related Materials 


\section{NATO ASI Series}

\section{Advanced Science Institutes Series}

A Series presenting the results of activities sponsored by the NATO Science Committee, which aims at the dissemination of advanced scientific and technological knowledge, with a view to strengthening links between scientific communities.

The Series is published by an international board of publishers in conjunction with the NATO Scientific Affairs Division
A Life Sciences
B Physics
C Mathematical and Physical Sciences
D Behavioural and Social Sciences
E Applied Sciences
F Computer and Systems Sciences
G Ecological Sciences
H Cell Biology
I Global Environmental Change

\section{PARTNERSHIP SUB-SERIES}

1. Disarmament Technologies

2. Environment

3. High Technology

4. Science and Technology Policy

5. Computer Networking
Plenum Publishing Corporation

London and New York

Kluwer Academic Publishers

Dordrecht, Boston and London

Springer-Verlag

Berlin, Heidelberg, New York, London, Paris and Tokyo

Kluwer Academic Publishers

Springer-Verlag / Kluwer Academic Publishers

Kluwer Academic Publishers

Kluwer Academic Publishers

Kluwer Academic Publishers

The Partnership Sub-Series incorporates activities undertaken in collaboration with NATO's Cooperation Partners, the countries of the CIS and Central and Eastern Europe, in Priority Areas of concern to those countries.

\section{NATO-PCO-DATA BASE}

The electronic index to the NATO ASI Series provides full bibliographical references (with keywords and/or abstracts) to more than $\mathbf{5 0 0 0 0}$ contributions from international scientists published in all sections of the NATO ASI Series.

Access to the NATO-PCO-DATA BASE is possible in two ways:

- via online FILE 128 (NATO-PCO-DATA BASE) hosted by ESRIN, Via Galileo Galilei, 1-00044 Frascati, Italy.

- via CD-ROM "NATO-PCO-DATA BASE" with user-friendly retrieval software in English, French and German (๑ WTV GmbH and DATAWARE Technologies Inc. 1989).

The CD-ROM can be ordered through any member of the Board of Publishers or through NATO$\mathrm{PCO}$, Overijse, Belgium.

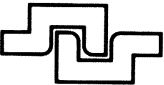

3. High Technology - Vol. 38 


\section{Diamond Based Composites and Related Materials}

edited by

Mark A. Prelas

University of Missouri, Columbia, MO, U.S.A.

\section{Andrew Benedictus}

University of Missouri,

Columbia, MO, U.S.A.

\section{Li-Te Steven Lin}

The Institute of Physics, Academia Sinica,

Taipei, Taiwan, R.O.C.

\section{Galina Popovici}

University of Illinois,

Urbana, IL, U.S.A.

and

\section{Peter Gielisse}

Florida State University, Florida A\&M University,

Tallahassee, FL, U.S.A.

Springer Science+Business Media, B.V. 
Proceedings of the NATO Advanced Research Workshop on

Diamond Based Composites

St. Petersburg, Russia

June 21-22, 1997

A C.I.P. Catatogue record for this book is available from the Library of Congress

\section{All Rights Reserved}

(C) 1997 Springer Science-Business Media Dordrecht

Originally published by Kluwer Academic Publishers in 1997

Softcover reprint of the hardcover 1st edition 1997

No part of the material protected by this copyright notice may be reproduced or utilized in any form or by any means, electronic or mechanical, including photocopying, recording or by any information storage and retrieval system, without written permission from the copyright owner. 


\title{
ACKNOWLEDGMENT
}

NATO ADVANCED RESEARCH WORKSHOP

DIAMOND BASED COMPOSITES

\author{
Sponsored by: \\ North Atlantic Treaty Organization \\ Office of Naval Research (London) \\ University of Missouri-Columbia \\ Laboratory, A.F.Ioffe Phys.-Technical Institute
}




\section{TABLE OF CONTENTS}

\section{Part 1. Diamond and Related Based Composites}

Advance Composite Materials On the Diamond Base

S.K. Gordeev

Diamond Composites for Grinding Applications

S. Ramanath, S.T. Buljan, R.D. Grieger

Hot Pressing of Nanodiamond Powder

G. Popovici, M.A. Prelas, F. Golshani, P. Han and

K.E. Huggins

Chemical Vapor Deposition of Diamond Films on Diamond Compacts

V.G. Ralchenko, S.M. Pimenov, V.G. Pereverzev, I.I. Vlasov,

S.V. Lavrischev, E.D. Obraztsova, V.I. Konov, E.V.

Shorokhov, D.M. Lebedev, M.A. Lebedev, B.K. Vodolaga,

E.N. Loubnin, V.A. Spivak

The Diamond and Hard Alloy-Based Composite Material

V.S. Urbanovich

Growth Kinetics of Cubic Boron Nitride Films and Composites

Charles A. Taylor II and Roy Clarke

Phase Transformations In Ultradispersed Boron Nitride under the

Conditions of High Pressures and Temperatures

N.I. Poloushin, I.I. Bairamgoulov, V.I. Choukalin,

V.N. Troitskiy

Composite Materials Based on Cubic Boron Nitride: Structure and Properties

V.B. Shipilo, N.G. Anichenko, I.M. Starchenko, and E.M. Shishonok 
viii

Comparion Between DC and RF Magnetron Sputtered Aluminum

Nitride Films

C.C. Morosanu, V. Dumitru, Elena Cimpoiasu,

Cristina Nenu

Aluminum Nitride Composite Films

B.V. Spitsyn, A.F. Belyanin, L.L. Bouilov, A.N. Blaut-

Blachev, V.P. Stoyan

Allotropic Forms of Carbon Nitride

A. Sokolowska, J. Szmidt, J. Konwerska-Hrabowska,

A. Werbowy, A. Olszyna, K. Zdunek, S. Mitura

Phase Transition in C:N Films under Shock Wave Compression

M.B. Guseva, V.G. Babaev, V.M. Babina, V.V. Khvostov,

A.Z. Zhuk, A.A. Lash, I.A. Fedorinin

\section{Part 2. Nanoclusters}

Copper Nanoclusters in DLC

V.I. Ivanov-Omskii

X-ray Absorption Study of Copper Clusters Embedded into

Hydrogenated Amorphous Carbon

A.V. Kolobov, K. Takanaka, H. Oyanagi, S.G. Yastrebov,

V.I. Ivanov-Omskii, V.I. Siklitsky

Fractal Structure of Copper Clusters Embedded in DLC

V.I. Ivanov-Omskii, V.I. Siklitsky, M.V. Baydakova

On the Copper-Carbon Interaction in Cu-Doped Diamond-Like

Carbon

E.A. Smorgonskaya and V.I. Ivanov-Omskii

Verification of Nanocrystalline Diamond Films' Quality

M. Langer, S. Mitura, Jan Szmidt, A. Sokolowska

\section{Part 3. Properties}

The Surface Structure of Carbon Films Deposited by Different

Plasmachemical Methods

S. Mitura, E. Mitura, P. Niedzielski, M. Dtuzniewski, E.

Staryga, S. Der-Sahagian, J. Zak, A. Sokolowska, J. Szmidt, A. Stanishevski 
Direct Observations of the Elastic Modulus and Tensile Strength of

CVD Diamond Films and Fibers

J.L. Davidson

Magnetic Resonance Studies of Solid-State Hydriogen and Hydrogen-Related Defects

K.M. McNamara Rutledge, G.D. Watkins, X. Zhou,

K.K. Gleason

Photothermal Determination of the Thermal Conductivity of

Superhard Thin Films

J. Mazur, J. Bodzenta, Z. Kleszczewski

Effect of Light on the Performances of CVD Diamond Nuclear

Detectors

C. Manfredotti, F. Fizzotti, P. Muzzani, P. Polesello,

E. Vittone

Open-Circuit Mobility Measurements in DLC Thin Films

M.Dluzniewski, P. Stepnik, E. Staryga, G.W.Bak, S. Mitura

Native and Light Induced Defect States in Wide Band-Gap

Hydrogenated Amorphous Silicon-Carbon $\left(A-\mathrm{Si}_{1-\mathrm{x}} \mathrm{C}_{\mathrm{x}}: \mathrm{H}\right)$

Alloy Thin Films

Mehmet Günes

Genesis of Defects Suitable For High-Temperature Spectral Hole

Burning in Diamond

301

A. Osvet and I. Sildos

Raman Spectroscopy of Amorphous Diamondlike Carbon Films

Produced With a Mass-Separated Ion Beam and Pulsed Arc

Discharge

L. Yu. Khriachtchev, M. Räsänen, R. Lappalainen and

M. Hakovirta

ESR Study of Neutron Irradiated Doped Diamond Films

V.S. Varichenko, A.A. Melnikov, N.M. Penina,

M.A. Prelas, S. Khasawinah, T. Sung, G. Popovici 
A.A. Melnikov, A.M. Zaitsev, A.S. Shulenkov,

V.S. Varichenko

Nature of the Origin of Non-Linear Current Voltage Characteristics in Polycrystalline Diamond Materials

N.D. Samsonenko, N.I. Nosanov and S.N. Samsonenko

Radiation Induced Modifications of Diamond

S.A. Khasawinah, M.A. Prelas and G. Popovici

Nanophase Diamond Containing Material Based on Detonation Synthesis Powders

V.B. Shipilo, I.M. Starchenko, E.V. Zvonarev, and

V.T. Senyut

Cluster Polymers Composites on Basis of Diamond Containing Nanocarbon of Explosive Synthesis

A.P. Voznyakovskii and V.Yu. Dolmatov

Superhard Composites of Cubic Boron Nitride

A.V. Bochko

Issues In c-BN Composites

Peter J. Gielisse

Workshop Participants

Index of Authors

Index 


\section{FOREWORD}

The objective of this meeting was to discuss the state of the art in the development of advanced composite materials using wide band gap materials (diamond and cubic boron nitride) and potential applications for these materials. The goal of this workshop was to bring together the scientific and industrial communities. It is well known that the level of materials science in the Former Soviet Union was very high. Specifically, there has been a great deal of work done on diamond and other wide band gap based composites. The Diamond (and other wide band gap) Based Composites (DBC) workshop was designed to bring together leaders in the scientific community and industry of the western and former eastern block countries to engage in discussions in this important technical area. Only with this free exchange can both the western and eastern communities fully understand the state of the discipline, to understand what research avenues to pursue, and to advance the development of the DBC technology for applications.

Diamond-based composites offer the advantages of diamond and related materials like hardness, high Young's modulus as well as other properties. These material have demonstrated new and unexpected features like unusual stability against high temperature and pressure shocks, a large internal surface that can be technologically controlled, a possibility to control electric, magnetic and optical properties etc... A feasibility of controlling internal surface variation over wide limits offers potential for DBC applications as efficient filters, absorbent, sensors and other tools of environmental control and monitoring.

The DBC NATO Advance Research Workshop covered topics including problems of synthesis of the materials, their characterization and properties. Significant attention was paid to trends in high pressure and high temperature technology. Additionally, low pressure technologies for synthesis of DBC and related materials was addressed. One of the highlights of the conference is a description of achievements in nanocomposite technology. Basic principles of DBC material science was considered with an accent on future developments in the fields of electronics, optics, industrial tools and components, biotechnology and the medicine.

The workshop focused on the issues of development of wide band-gap materials in composites. The topics ranged from molecular clusters, nanophase materials, growth, processing, and synthesis. Commercial composite materials have been on the market for a number of years specifically as abrasives.

The processing of composite based materials can be categorized by six basic methods: 1) In situ growth - high pressure high temperature "catalytic" conversion; 2) mix and sinter such as c-BN plus metal (ceramic polymer) mix; 3) direct sintering; 4) direct polymorphic conversion; 5) shock detonation; 6) SHS sintering. 
xii

One of the highlights of the meeting was the work by Guseva and Babaev in which linear chain $\mathrm{N}$-doped carbon films were created with s-p hybridization. These films underwent shock wave compression to transform the $\mathrm{C}(\mathrm{sp}): \mathrm{N}$ to $\mathrm{C}\left(\mathrm{sp}^{3}\right): \mathrm{N}$. This work detailed the characterization of the material which indicated that carbon nitride was formed.

Mark A. Prelas

University of Missouri

Columbia, MO 65211 USA

Li-Te Steven Lin

The Institute of Physics, Academia Sinica

Taipei 11529, Taiwan, R.O.C.

Peter Gielisse

Florida State University

Florida A\&M University

Tallahassee, Florida 32310

\section{Andrew Benedictus}

University of Missouri

Columbia, MO 65211 USA

\section{Galina Popovici}

University of Illinois

Urbana, Illinois 61820 USA 